\title{
The 34th SICOT orthopaedic world congress
}

\author{
Maurice Hinsenkamp
}

Received: 13 June 2013 / Accepted: 14 June 2013 / Published online: 4 July 2013

(C) Springer-Verlag Berlin Heidelberg 2013

SICOT remains on track with its continuous expansion. The membership has now reached 11,500 members with a large representation in Asia and Europe. Our Journal International Orthopaedics offers you 4,062 articles available online and its impact factor is 2.319 in 2012.

The scientific programme of our next meeting in Hyderabad is extremely promising. The number of submitted abstracts continues to increase each year. During the three-day meeting from 17 to 19 October you will be able to attend four plenary lectures, an Educational Day on Trauma, 32 symposia, 15 instructional courses, multiple workshops, and no less than 46 free paper sessions in ten parallel rooms.

The plenary speakers are José Sergio Franco, Dror Paley, Shanmuganathan Rajasekaran, and Steffen Ruchholtz. They have been chosen for their outstanding expertise and will lecture on proximal humerus fractures, on limb lengthening and deformity correction, on spine, and on the management of polytrauma, respectively.

This year the theme of the Educational Day (ED) is Trauma. The expert Faculty from ten different countries will be delivering their specialist lectures throughout the day. The two previous ED in Prague and Dubai were respectively on the hip and knee and were very successful. The aim of the SICOT ED is to provide a comprehensive review course for residents and an evidence-based update for experienced surgeons.

The 15 Instructional Courses (IC) will cover the main and more specialised aspects of our profession from polytrauma management to microsurgery and tissue engineering. As in previous years, an IC will be devoted to "How to write a paper" with the participation of the Editor of International Orthopaedics, Marko Pecina.

\section{Hinsenkamp $(\square)$}

Department of Orthopaedic Surgery,

Hôpital Erasme, Université Libre de Bruxelles, route de Lennik, 808, B-1070 Brussels, Belgium

e-mail: mhinsenk@ulb.ac.be

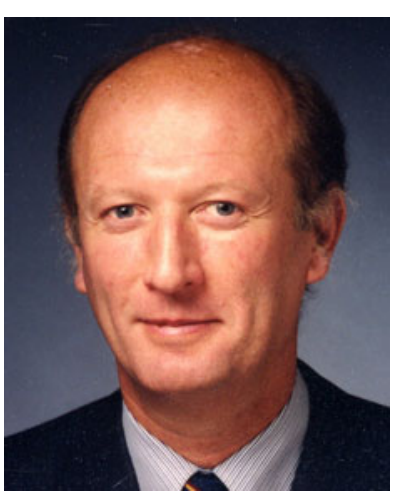

Apart from the most frequently represented topics, such as hip and knee arthroplasties and spine, others have been given a special focus in Hyderabad. Our Trauma Committee has prepared symposia on fractures of the pelvis and acetabulum, trauma prevention, and one IC on polytrauma. The Paediatrics Subspecialty Committee has organised one IC and two symposia in addition to the free paper sessions.

This year, orthopaedic oncology represented a significant percentage of submitted abstracts and, in addition to the free paper sessions, one IC and one symposium will cover bone tumours more thoroughly with the participation of a representative of WHO on tissue transplantation.

Regarding natural disasters and preparing volunteer orthopaedic surgeons for humanitarian missions, in Gothenburg we had a session on the debriefing of the medical response in Haiti, in Prague on amputation [1], and in Dubai on triage [2]. This year it will be on external fixation, in addition to an IC and a hands-on workshop on external fixation.

For those who would like to receive more practical information on humanitarian missions, Médecins Sans Frontières (Doctors Without Borders) will be present at the Congress with a booth at the scientific exhibition.

This year specialty societies such as APOA, ARTOF, ASAMI, EIBEJS, IFPOS, SOFCOT and WOC will further 
explore more specific aspects. The SOFCOT Symposium will present the causes for revision of Primary Total Hip Arthroplasty in France.

I remind you also that during the meeting several awards will be granted to young trainees and more experienced orthopaedic surgeons to recognise their excellent work. These include the Lester Lowe SICOT Awards, Henri Bensahel Award, SICOT/AAOS Annual Meeting Scholarships, SICOT/CCJR Meeting Awards, SICOT Oral Presentation Awards, and SICOT Poster Awards. More details can be found on the SICOT website.

The local Committee chaired by Ashok Johari has prepared memorable social events in the city of Hyderabad, which was founded in the 11th century on the Golconda hill and is now a city of around seven million people, including Cyberabad. Palaces and historical venues illustrate its development and will give you an enchanting taste of India.

\section{References}

1. Hinsenkamp M (2012) SICOT contribution to natural disasters assistance. Int Orthop 36(10):1977-8

2. Hinsenkamp M (2013) SICOT contribution to natural disaster assistance: the triage. Int Orthop. doi:10.1007/s00264-013-1987-1 